\title{
Household Characteristics, Housing Profile and Diet Diversity of Pantawid Pamilyang Pilipino Program (4Ps) Beneficiaries and Non-beneficiaries in Lucena City, Quezon, Philippines
}

\author{
Ma-Ann M. Zarsuelo, ${ }^{1}$ Madeline M. Suva, ${ }^{2}$ Clarissa B. Juanico ${ }^{3}$ and Wilma A. Hurtada ${ }^{3}$ \\ ${ }^{1}$ Institute of Health Policy and Development Studies, National Institutes of Health, University of the Philippines Manila \\ ${ }^{2}$ College of Development Communication, University of the Philippines Los Baños \\ ${ }^{3}$ Institute of Human Nutrition and Food, University of the Philippines Los Baños
}

\begin{abstract}
Background. The Philippines adopted the Conditional Cash Transfer (CCT) program as the Pantawid Pamilyang Pilipino Program (4Ps) that serves as the government's flagship social assistance program for the poor. This provides short-term income support to poor families while investing on health and education to overcome future poverty.

Objective. This study aimed to characterize the beneficiary and non-beneficiary households and evaluate the impact of 4Ps program on housing facilities and diet diversity.
\end{abstract}

Methods. Quasi-experimental design was used to evaluate survey outcomes between 91 randomly sampled beneficiaries and 91 completely enumerated non-beneficiaries (incoming grantees). FANTA Household Dietary Diversity Score (HDDS) was used as an indicator for dietary diversity while structured questionnaire on housing profile was based on BIDANI and CEM-UPLB tools.

Results. The 4Ps beneficiaries had significantly higher maternal education, household size $(\rho=0.038)$, and improved water source $(\rho=0.004)$ than non-beneficiaries. Cash transfer among 4Ps households provided $11 \%$ increase in the average monthly income of P7,324 pre-transfer. Diet diversity using FANTA scoring (0-12) showed that nonbeneficiaries were significantly lower by 0.4 than 4Ps score of $7.9(\rho=0.003)$. Maternal education was found to have significant positive correlation with diet diversity. Both groups had high cereals and fats intake (>90\%) while low in complex carbohydrates and legumes $(<31 \%)$.

Conclusion. The 4Ps had positive correlation on housing profile and diet diversity among beneficiaries. Family Development Session should integrate practical methods on improving variety of foods, specifically, the low consumption food groups. Additionally, a review on the selection criteria based on the provincial poverty threshold vis a vis income of grantees must be implemented to accurately target intended beneficiaries.

Key Words: conditional cash transfer, dietary diversity, impact assessment

\section{INTRODUCTION}

Corresponding author: Ma-Ann M. Zarsuelo Institute of Health Policy and Development Studies National Institutes of Health

University of the Philippines Manila

623 Pedro Gil Street, Ermita, Manila 1000, Philippines

Telefax: +6323543832

E-mail: mmzarsuelo@up.edu.ph
Poverty remains a big challenge in the Philippines in spite of continued economic growth, as observed in the past decade. This supports the fact that structural poverty persists to be a binding constraint in sustainable growth and attainment of Sustainable Development Goals (SDGs). To help alleviate the poverty in the country and meet population consumption needs while fostering investment in human capital, the Philippines launched a Conditional Cash Transfer (CCT) program in $2008^{1}$. This program 
provides short-term income support to poor families to help meet their immediate needs while enhancing their human capital to overcome future poverty. It provides cash to eligible households with good compliance to education and health conditionalities. ${ }^{2}$

The Philippines' CCT has been named the Pantawid Pamilyang Pilipino Program (4Ps). It has two grants-a monthly health grant of Php 500 per household for 12 months and an education grant of Php 300 per 6-14-yearold child attending school (maximum of 3 children) for 10 months of the school year. Additionally, health care commitment is applicable to pregnant mothers and children aged 0-5 years. Should a beneficiary household satisfy all conditionalities, a maximum health grant of $\mathrm{Php} \mathrm{6,000} \mathrm{and}$ education grant of Php 3,000 per child will be received for each year. ${ }^{2}$

The conditionalities include: (1) pregnant women must avail of the pre- and post-natal care and must be attended by a trained medical professional during childbirth; (2) parents must attend monthly Family Development Session (FDS); (3) children aged 0-5 years must undergo regular preventive health checks and receive vaccines; (4) children aged 3-5 years must attend day care or preschool classes at least 85 percent of the time; (5) children aged 6-14 years must enroll in elementary or high school and attend at least 85 percent of the time; and (6) children aged 6-14 years old must receive deworming pills twice a year. The family-beneficiaries will receive the grant for at most five years, provided that they comply with the conditionalities. ${ }^{3}$

The FDS serves as a platform to discuss with parents or guardians topics on family relationships, laws affecting the Filipino families, gender and development, parental obligations, and positive child discipline. This enables households to become socially aware and be pro-active in community development activities. There are three modules in FDS namely: (1) Building the foundation in the Pantawid Pamilya program, (2) Preparing and caring of Filipino families, and (3) Participation of Filipino families in community activities. Moreover, FDS plus is an enhanced package with a range of complementary communitybased initiatives not included as conditionalities to the grantees. These activities aim to promote, develop and target participants to attain concrete and tangible outputs after active participation in lecture series and interactive demonstrations. ${ }^{4}$

For the effect on income of Pantawid Pamilya program, the benefit level is relatively generous on the basis of estimated equivalent income percentage of monthly cash grant compared to the CCT of other countries. ${ }^{5}$ In the Philippines, if all conditions are met, grants are estimated to be 23 percent of the beneficiary income, which is at par to that of Mexico's Opportunidades program in 2004. This is comparatively higher than Brazil (Bolsa Familia program) which was 5 percent in $2004{ }^{1}$

The CCT program also aids in the family's nutritional status by increasing the economic access of beneficiary households to food. Consequently, it is expected to translate to better health and nutrition outcomes. Food and nutrition outcomes can be determined using the household dietary diversity score (HDDS), which reflects a snapshot of economic access to a variety of food while individual DDS reflects nutrient adequacy. ${ }^{6} \mathrm{~A}$ more diverse diet is a good proxy indicator of food security since it is positively associated with improved outcomes in birth weight, child anthropometric status, and hemoglobin concentrations; and is highly correlated with caloric and protein adequacy. ${ }^{7}$ It was observed that even in very poor households, additional income can lead to increased food expenditure which is associated with improved diet quantity and quality. ${ }^{7}$

To ensure the maximum efficacy of the program, further evaluation on its outcomes would aid in the continuous assessment and improvement of the program. This study focused on evaluating the impact of 4Ps on the housing facilities and diet diversity.

\section{MATERIALS AND METHODS}

\section{Study Population}

This study included 4Ps beneficiaries and nonbeneficiaries in Lucena City, Quezon, Philippines.

\section{Study Design and Sampling}

The study employed an evaluation design using quasiexperimental case control design. This is used to carry out evaluation when it is not possible to construct treatment and control group using random assignment. ${ }^{8}$ The design estimates program impact by comparing outcomes among the 4Ps beneficiaries in the treatment group against the incoming beneficiaries as a proxy for non-beneficiaries which serves as the control. ${ }^{1}$ Selection of households should satisfy inclusion criteria of $4 \mathrm{Ps}$ grantees, that are on the average, equal across the treatment and control groups. As a result, it establishes a credible basis for comparison and direction of causality. ${ }^{9}$

The study had two sample groups wherein 4Ps beneficiaries were randomly sampled while non-beneficiaries were completely enumerated. Because there were 91 nonbeneficiary households (incoming grantees), an equal number of 4 Ps beneficiaries were thus randomly selected. Therefore, results among non-beneficiaries reflected the true value of the population while statistical weighting was applied in $4 \mathrm{Ps}$ beneficiaries for better population representation.

\section{Data Collection}

Data collection on household profile was conducted through a structured questionnaire based on the tools of Barangay Integrated Development Approach for Nutrition Improvement (BIDANI) and the College of Economics (CEM), University of the Philippines Los Baños. This includes basic household characteristics, economic status and 
housing facilities. In determining the diet diversity, FANTA Household Dietary Diversity Score (HDDS) was used. The HDDS consists of 16 food groups that were further aggregated into 12 groups for analysis. All the tools had been developed and tested for validity and reliability.

\section{Data Analysis}

Data entry was done using Microsoft Excel and SPSS (Ver. 20) for statistical analyses. Descriptive statistics were reported as frequencies, percentages, means and standard deviations ( $\pm \mathrm{SD})$. Statistical weighting was applied in 4Ps group for better population representation. Phi Cramer's $\mathrm{V}$ was used in determining the association of household profile and housing facilities, against a sample which may be classified as a beneficiary or non-beneficiary. Meanwhile, for continuous variables, one-sample t-test was used in determining the significant difference of diet diversity and household characteristics between the two groups. Pearson Product correlation was used in determining relationship of "diet diversity" with continuous data such as "household size" and "income" while Spearman rank order correlation was used for associating "diet diversity" with "maternal education".

\section{RESULTS AND DISCUSSION}

\section{Socio-demographic Profile and Characteristics}

One of the major bases of Pantawid Pamilya program in identifying potential beneficiaries is through the sociodemographic and economic profiling including housing facilities of the households. The Department of Social Welfare and Development (DSWD) uses the National Household Targeting System for Poverty Reduction (NHTS-PR) to identify the poorest households within the selected municipalities through the use of Proxy Means Test (PMT). Assessment is conducted using certain proxy variables like ownership of assets, type of housing, education and employment of household head, and access to water and sanitation facilities to predict income. ${ }^{3}$

\section{Household profile}

Beneficiaries of $4 \mathrm{Ps}$ had significantly higher household size $(\rho=.038)$ with the average of 6.3 vs. 5.9 in non-beneficiaries (Table 1). On the other hand, nonbeneficiary households had higher monthly income than 4Ps with the average of Php 7,958 vs. 7,324. Assuming

Table 1. Percentage distribution of household characteristics and housing facilities of 4Ps beneficiary and non-beneficiary households

\begin{tabular}{|c|c|c|c|}
\hline Variable & 4Ps Beneficiaries & Non-beneficiaries & p-value \\
\hline \multicolumn{4}{|l|}{ Household Size (number of members) } \\
\hline $1-3$ & 3.2 & 6.6 & \multirow{6}{*}{$0.038^{1}$} \\
\hline $4-6$ & 57.0 & 60.4 & \\
\hline 7-9 & 33.0 & 28.6 & \\
\hline$>10$ & 6.6 & 4.4 & \\
\hline Mean \pm SD & $6.3 \pm 1.7$ & $5.9 \pm 2$ & \\
\hline Range & $3-10$ & $2-12$ & \\
\hline \multicolumn{4}{|l|}{ Monthly Household Income (Php) (absolute value) } \\
\hline Mean \pm SD & $\begin{array}{c}7324 \pm 4117 \text { (pre-transfer) } \\
8124 \pm 4137 \text { (post-transfer) }\end{array}$ & $7958 \pm 5470$ & \multirow[t]{2}{*}{$0.271^{1}$} \\
\hline Range & $\begin{array}{l}1000-20000 \\
1800-20800\end{array}$ & $0-36000$ & \\
\hline \multicolumn{4}{|l|}{ Toilet Facility } \\
\hline Owned, water sealed (sewage/septic tank)) & 38.6 & 27.5 & \multirow[t]{4}{*}{$0.364^{2}$} \\
\hline Owned, opened/closed pit & 31.8 & 40.7 & \\
\hline Shared/public, water sealed & 19.4 & 19.7 & \\
\hline Shared, opened/closed pit & 10.2 & 12.1 & \\
\hline \multicolumn{4}{|l|}{ Water source } \\
\hline Own use, faucet tube/piped well & 17.6 & 11.0 & \multirow[t]{4}{*}{$0.004^{2}$} \\
\hline Shared faucet, community water system & 34.1 & 31.8 & \\
\hline Shared, tube/piped well & 15.3 & 12.1 & \\
\hline Others (specify) & 33.0 & 45.1 & \\
\hline \multicolumn{4}{|l|}{ Electricity } \\
\hline Owned, electricity line & 89.0 & 87.9 & \multirow[t]{4}{*}{$0.998^{2}$} \\
\hline Gas & 3.3 & 3.3 & \\
\hline None & 5.5 & 6.6 & \\
\hline Others & 2.2 & 2.2 & \\
\hline \multicolumn{4}{|l|}{ Garbage Disposal } \\
\hline Collected & 71.6 & 72.5 & \multirow{4}{*}{$0.767^{3}$} \\
\hline Compost pit & 4.5 & 3.3 & \\
\hline Burned & 23.9 & 24.2 & \\
\hline Others & 0 & 0 & \\
\hline \multicolumn{4}{|l|}{ Household Dietary Diversity Score } \\
\hline Mean \pm SD & $7.9 \pm 1.3$ & $7.5 \pm 1.4$ & \multirow[t]{2}{*}{$0.003^{1}$} \\
\hline Range & 5-11 & 4-11 & \\
\hline
\end{tabular}

${ }^{*}$ Assuming a minimum of monthly Php 800.00 cash grant. ${ }^{1}$ One sample t-test. ${ }^{2}$ Phi Cramer's V. ${ }^{3}$ Chi square. 
that $4 \mathrm{Ps}$ households with a minimum of one child satisfy all conditionalities, a monthly cash grant of Php 800 will be received. Hence, 4Ps grants increased the income (Php $8,124 \pm 4,137)$, contributing to an 11 percent increase in monthly income.

A study from World Bank showed that consumers in low-income countries make greater adjustments in their household spending on food when incomes and/or prices change. In particular, it is estimated that an increase of 10 percent household income would lead a consumer in the Philippines to typically increase food spending by 6.5 percent. $^{10}$

Moreover, the average income of both groups had a wide value range with positively skewed distribution. Beneficiaries of 4Ps had an income range of Php 1,000-20,000 (skewness of 1.160) while range was Php 0- 36,000 (skewness of 2.049) for non-beneficiaries. This might reflect conflict on one of the $4 \mathrm{Ps}$ selection criteria which states that eligible grantees must be families whose condition is equal to or below the provincial poverty threshold.

The educational attainment and unemployment status of mothers in 4Ps households was higher than those of the non-beneficiaries. ${ }^{11}$ Lower employment among 4Ps respondents could be accounted by the financial support from the cash grant. In addition, commitment to the conditionalities becomes the priority of mothers in the context of time allotment. Hence, they had less time opportunity to seek work.

Among the parameters, there was a significant association between the household income and size for both 4Ps beneficiaries $(r=0.399, \rho=.000)$ and non-beneficiaries $(r=0.470, \rho=.000)$ (Table 2). Trend in raw data showed that as household size increased, the number of working members increased accordingly, hence, leading to higher household incomes.

Table 2. Association of household characteristics variables

\begin{tabular}{lcc} 
Association variable & Correlation value & p-value \\
HH Income to HH size $^{1}$ & 0.459 & 0.000 \\
4Ps beneficiaries $^{1}$ & 0.399 & 0.000 \\
Non-beneficiaries $^{1}$ & 0.470 & 0.000 \\
HH Income to Maternal education $^{2}$ & 0.010 & 0.894 \\
4Ps beneficiaries $^{2}$ & -0.058 & 0.583 \\
Non-beneficiaries $^{2}$ & 0.097 & 0.358 \\
HH Size to Maternal education $^{2}$ & 0.019 & 0.801 \\
4Ps beneficiaries $^{2}$ & -0.031 & 0.774 \\
Non-beneficiaries $^{2}$ & 0.013 & 0.900 \\
\hline
\end{tabular}

${ }^{1}$ Pearson product correlation. ${ }^{2}$ Spearman rank order correlation.

\section{Housing Facilities}

One of the indicators of poverty index includes housing facilities. This includes sanitation facilities where related diseases become prevalent in low income communities. ${ }^{12}$ Results showed that almost half of both $4 \mathrm{Ps}$ beneficiaries and non-beneficiaries practiced open/close pit system (42 vs. 52.8\%). Much literature demonstrated that young children from households with unimproved sanitation facilities are of greater risk of being undernourished. ${ }^{13}$

In relation to this, water source is strongly linked to sanitation and hygiene, which in turn affects health. Majority of water source for both 4Ps beneficiaries (49.5\%) and nonbeneficiaries (44\%) were shared water supply. Meanwhile, only $17.6 \%$ of 4 Ps have their own faucet (tube/piped well), as compared to $11 \%$ for non-beneficiaries. Similarly, this causation could also explain the significant association of water source with being a 4 Ps beneficiary or not $(\rho=0.004)$. A significant percentage of non-beneficiaries (45.1\%) and $4 \mathrm{Ps}(33 \%)$ relied on vendor-water supply, wherein households were mostly in coastal barangays. These areas have high prevalence of slums where water sources are not well established.

For garbage disposal, more non-beneficiaries practiced better garbage disposal system than 4Ps beneficiaries, having higher proportion of collector system (72.5 vs. $69.2 \%)$. Studies showed that under-five children have higher prevalence of nematodes infection in households without proper isolation and collection of solid waste. ${ }^{14}$

For electricity line, more 4Ps beneficiary households than non-beneficiary households have their own line ( 89 vs. $87.9 \%)$ while a few $(5.5 \%$ vs. $6.6 \%)$ did not have electricity at all. This also indicates better economic access for improved facilities.

\section{Diet Diversity}

Household dietary diversity score (HDDS) was determined using FANTA (2010) tool in which food list were categorized into 16 food groups. For analysis, food groups with similar macronutrients are further aggregated to 12 groups. This reflects the economic food access of the household to a variety of foods. ${ }^{6}$ Results showed that dietary diversity of non-beneficiaries is significantly lower by 0.4 $(\rho=.003)$ with that of 4 Ps beneficiaries average score of $7.9 \pm$ 1.3. In general, $4 \mathrm{Ps}$ beneficiaries had better economic access to different food groups than non-beneficiaries, leading to a more diverse diet (Figure 1). It has been well recognized that higher economic status has positive relationship with diet diversity as affected by purchasing power. ${ }^{6,15}$ Similarly, this often leads to higher quality diet as defined by having nutrient- rather calorie-dense foods. ${ }^{15} \mathrm{~A}$ study in diet diversity demonstrated that it is positively associated with per capita caloric intake. ${ }^{6}$

The food groups that were highly consumed $(>90 \%)$ by both groups were: cereals; spices, condiments and beverages; and oils and fats. It was then followed by fish and other seafoods and vegetables being consumed by around 80 to $90 \%$ of households. This reflects that the typical household diet of the target population is similar with that of the national survey results-rice, fish, and vegetables. ${ }^{16}$ Other sources of carbohydrates like tubers were less consumed by both 4Ps beneficiaries (19.8\%) and non-beneficiaries (11\%).

Among all the macronutrients, it is evident that other protein sources was consumed by less than half of the 


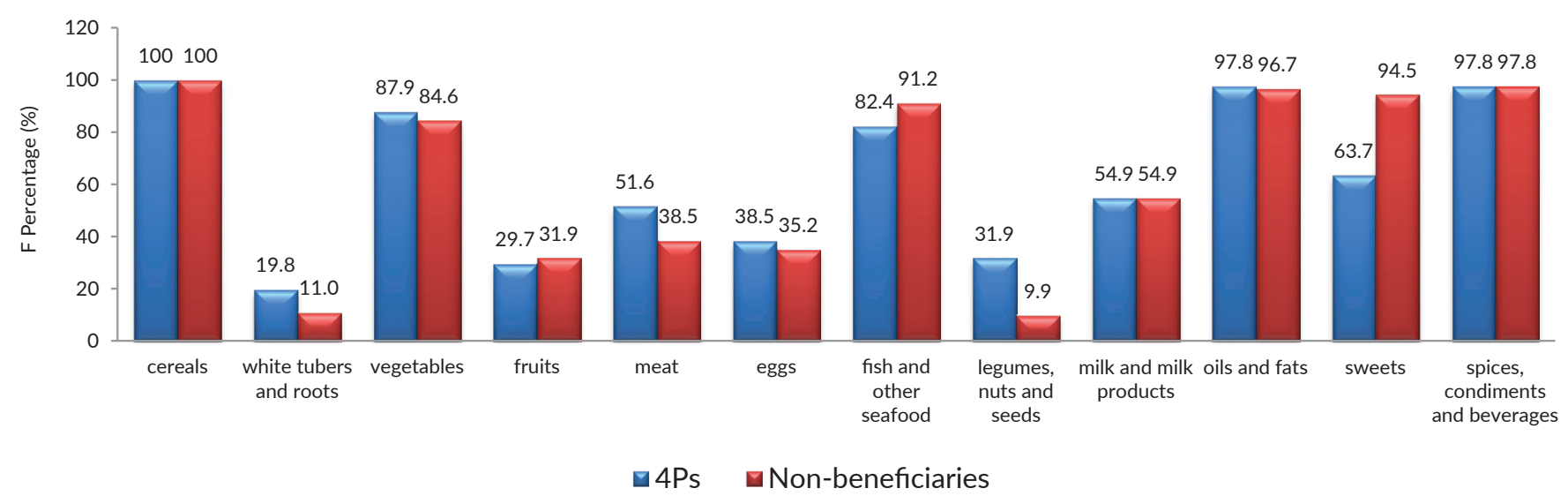

Figure 1. Percentage distribution of different food group consumption of 4Ps and non-beneficiary households.

households in both groups wherein 4Ps were higher than non-beneficiaries in the consumption of meat (51.6 vs. 38.5 \%); eggs (38.5 vs. $35.2 \%)$; and legumes, nuts, and seeds (31.9 vs. $9.9 \%)$. In addition, around half of both groups consumed milk and milk products, mostly powdered filled milk in coffee and less often, cheese.

Fruits and vegetables food groups are proxy indicator of the household micronutrient sources, specifically, iron and vitamins $\mathrm{A}$ and $\mathrm{C}$. Only one third of both groups consumed fruits, which was higher among non-beneficiaries than 4Ps beneficiaries (31.9 vs. $29.7 \%$ ). Meanwhile, more than half of both groups consumed leafy vegetables and other vegetables such as eggplant, tomato and onions while less Vitamin A rich vegetable was consumed. As reported by the households, fruits are more expensive than vegetables, and therefore, not a usual part of their daily diet.

Lastly, non-beneficiaries were 30.8 percentage points higher than 4Ps beneficiaries (94.5 vs. $63.7 \%$ ) in "sweets" consumption which were mostly sugar, sweetened juice drinks, and candies. A similar trend was observed in another study showing higher consumption of sugar and sweetened beverage among lower income households. ${ }^{17}$

In general, diet quality of $4 \mathrm{Ps}$ beneficiaries and nonbeneficiaries were high in fats and sweets, low in complex carbohydrates, and main protein intake was more from animal rather than plant sources. This pattern could be accounted to urbanization of the area where nutrition transition is greatly linked. ${ }^{18}$

In associating HDDS with different determinants, maternal education of both groups showed a positive correlation $(r=0.153, \rho=.040)$ (Table 3). Similar studies showed that higher maternal educational attainment is associated with improved quality of food consumption and diet diversity as there is a higher tendency for an educated mother to consider health on food choices. ${ }^{19,20}$ Meanwhile, only among non-beneficiary households did monthly income have a positive correlation with diet diversity $(r=0.228$, $\rho=.030$ ). Higher household income is a strong determinant of diet diversity as it increases food access. ${ }^{21,22}$
Table 3. Association of household dietary diversity score to household characteristics

\begin{tabular}{ccc}
\hline Association variable & Correlation value & p-value \\
Household Size $^{1}$ & 0.113 & 0.127 \\
4Ps beneficiaries $^{1}$ & 0.015 & 0.866 \\
Non-beneficiaries $^{1}$ & 0.162 & 0.125 \\
Household Income $^{1}$ & 0.220 & 0.465 \\
4Ps beneficiaries $^{1}$ & 0.044 & 0.681 \\
Non-beneficiaries $^{1}$ & 0.228 & 0.030 \\
Maternal education $^{2}$ & 0.153 & 0.040 \\
4Ps beneficiaries $^{2}$ & 0.221 & 0.035 \\
Non-beneficiaries $^{2}$ & 0.109 & 0.305 \\
\hline
\end{tabular}

${ }^{1}$ Pearson product correlation. ${ }^{2}$ Spearman rank order correlation.

\section{CONCLUSION AND RECOMMENDATIONS}

The 4Ps in Lucena City had positive correlation on housing profile and diet diversity among beneficiaries.

Impact evaluation on nutritional status of 0-5 year-old children showed that all forms of malnutrition among 4Ps beneficiary households are still high. ${ }^{11}$ Hence, addressing all possible contributing factors such as household profile, sanitary facilities and diet diversity should be considered. To maximize attainment of the intended program's objectives, it is recommended to integrate methods in improving dietary diversity in the Family Development Seminar. This includes alternative food sources to low consumption food groups or providing smart measures in maximizing a household's monetary budget for food without sacrificing diet diversity. For further improvement, expanding cash assistance for sanitation facilities such as toilet and water sources could have long term positive impact. Possible means of community activities could be integrated in the current FDS plus. This includes pro-active provision of income generating activities for beneficiaries in partnership with the local government units; financial assistance in exchange for community work; and paid labor for beneficiaries in constructing sanitary facilities.

Improvement in the beneficiary targeting system should be heightened given that the average 4Ps monthly 
income was $\mathrm{Php} 7,324 \pm 4,117$. Moreover, almost a quarter of 4 Ps beneficiary households (23\%) and non-beneficiary households (24\%) had monthly income greater than Php 10,000 . One of the established selection criteria for eligible grantees is to have a condition equal to or below the provincial poverty threshold. In this case, Quezon province's per capita poverty threshold is Php 1,492...$^{23}$ Thus, targeting systems should have stronger measures for validation to assure that more eligible households are accommodated. Having strict monitoring measures on the compliance to selection criteria can be implemented. In this way, allocation of financial assistance could be granted to those deserving families within the poverty threshold.

\section{Acknowledgement}

The authors acknowledge the financial support of DOST-ASTHRDP scholarship, and the assistance extended by the following collaborators: Department of Social Welfare and Development (DSWD-Region IVA), City Link, City Health Center, and City administration's office of Lucena City.

\section{Statement of Authorship}

All authors have approved the final version submitted.

\section{Author Disclosure}

All authors declared no conflicts of interest.

\section{Funding Source}

This paper was funded by the DOST-ASTHRDP scholarship.

\section{REFERENCES}

1. Chaudhury N, Okamura Y. Conditional Cash Transfers and School Enrollment: Impact of the Conditional Cash Transfer Program in the Philippines. The World Bank Group. Philippine Social Protection Note. 2012; 6.

2. Velarde R, and Fernandez L. Welfare and Distributional Impact of the Pantawid Pamilyang Pilipino Program. The World Bank Group: Philippine Social Protection Note. 201; 3.

3. Reyes CM, Tabuga AD, Mina C, Asis R. Promoting Inclusive Growth through 4Ps. Philippine Institute for Development Studies. Discussion Paper Series. 2013; 09

4. 4Ps Social Marketing Unit. [Online] 2012 July 12. FAQs on the CSO Engagement in FDS and FDS Plus. June 2012 (cited July 2014). Available from http://pantawid.dswd.gov.ph/index.php/pantawidpamilya-cso-faq.

5. Grosh M, del Ninno C, Tesliuc E, et. al. For Protection and Promotion: The Design and Implementation of Effective Safety Nets. Washington, DC: World Bank. 2008.
6. Food and Agriculture Organization (FAO). Guidelines for measuring household and individual dietary diversity. Food and Agriculture Organization. 2010.

7. Swindale A, Bilinsky P. Household Dietary Diversity Score (HDDS) for Measurement of Household Food Access: Indicator Guide Food and Nutrition Technical Assistance (FANTA). 2006.

8. IPDET. Descriptive, Normative, and Cause-Effect Evaluation Designs, International Program for Development Evaluation Training. 2007.

9. Mallucio JA, Flores R. Impact Evaluation of a Conditional Cash Transfer Program: The Nicaraguan Red de Proteccion Social. International Food Policy Research Institute. 2004.

10. Department of SocialWelfare and Development (DSWD). Conditional Cash Transfer (CCT) Philippines - Improving the Human Capital of the Poor (Pantawid Pamilyang Pilipino Program). 4Ps Concept Paper for MCC. 2009.

11. Zarsuelo M, Hurtada W, Suva M, Juanico S. Nutritional Status of Children and Maternal Knowledge, Attitudes, and Practices of Conditional Cash Transfer (CCT) Beneficiaries and Non-Beneficiaries in Lucena City, Quezon, Philippines. International Proceedings of Chemical, Biological and Environmental Engineering. 2015; 86 (2): 8-15.

12. CHILD FUND. Improving sanitation in the Philippines [Online]. 2014 (cited September 2014). Available at https://www.childfund.org/ Improving-Sanitation-in-the-Philippines/.

13. Esrey S, Potash J, Roberts L, Shiff C. Effects of improved water supply and sanitation of ascariasis, diarrhoea, dracunculiasis, hookworm infection, schistosomiasis, and trichoma. Bulletin of the World Health Organization. 1991; 609-21.

14. Moraes L. Household solid waste bagging and collection and their health implications for children living in outlying urban settlements in Salvador, Bahia State, Brazil. Cad. Saúde Pública. 2007; 23.

15. Darmon N, Drewnowski A. Does social class predict diet quality? The American Journal of Clinical Nutrition. 2008; 87:1107-17.

16. FNRI-DOST. 8th National Nutrition Survey: 2013. Bicutan, Taguig City, Philippines. 2013.

17. French A, Wall M, Mitchell N. Household income differences in food sources and food items purchased. International Journal on Behavioral Nutrition and Physical Activity. 2010; 7: 77.

18. Popkin B. Achieving Urban Food and Nutrition Security in the Developing World: Urbanization and the Nutrition Transition. International Food Policy Research Institute. A 2020 Vision for Food, Agriculture, and the Environment. 2000; 3, 7.

19. Chirstianne LH, Hupkens, Ronal A. Knibbe, Maria J. Social class differences in food consumption: The explanatory value of permissiveness and health and cost considerations. The European Journal of Public Health. 2000

20. Mallard, S, Houghton L, Filteau S, et. al. Dietary Diversity at 6 months of Age is Associated with Subsequent Growth and Mediates the Effect of Maternal education on Infant Growth in Urban Zambia, The Journal of Nutrition. 2014; 144(11): 1818-25.

21. Baliwati YF, Briawan Dodik, Melani V. Validation of Household Dietary Diversity Score (HDDS) to identify food insecure households in industrial area. Pakistan Journal of Nutrition. 2015.14 (4): 234-8.

22. Rashid, D.A., L.C. Smith and T. Rahman. Determinants of dietary quality: evidence from Bangladesh. World Dev. 2011. 39: 2221-31.

23. Official Poverty Statistics of the Philippines: First Semester 2015. Philippine Statistics Authority Website [online] 2015 [cited 2018 July 21] Available at https://psa.gov.ph/sites/default/files/1st $\% 20 \mathrm{Sem} \% 20$ 2015\%20Poverty_Publication_0.pdf. 